\title{
The late Silurian-Middle Devonian long-term eustatic cycle as a possible control on the global generic diversity dynamics of bivalves and gastropods
}

\author{
Dmitry A. Ruban \\ Division of Mineralogy and Petrography, Geology and Geography Faculty, Southern Federal University, Zorge Street \\ 40, Rostov-na-Donu, 344090, Russian Federation; postal address: P.O. Box 7333, Rostov-na-Donu, 344056, Russian \\ Federation; e-mail: ruban-d@mail.ru
}

\begin{abstract}
A long-term eustatic cycle (fall and subsequent rise of the global sea level) embraced the late Silurian-Middle Devonian time interval. Potentially, these sea-level changes could drive global biodiversity. The stratigraphic ranges of 204 bivalve genera and 279 gastropod genera included into the famous Sepkoski database allow reconstructing changes in the total diversity and the number of originations and extinctions of these important groups of marine benthic macro-invertebrates during this interval. None of the recorded parameters coincided with the long-term global sea-level cycle. It cannot be not excluded, however, that the global sea-level changes did not affect the regions favourable for bivalve and gastropod radiation because of regional tectonic mechanisms; neither can it be excluded that the eustatic control persisted together with many other extrinsic and intrinsic controls. Interestingly, the generic diversity of gastropods increased together with a cooling trend, and vice versa. Additionally, the Ludlow, Eifelian, and Givetian biotic crises affected, probably, both fossil groups under study. There was also a coincidence of the relatively high bivalve generic diversity, initial radiation of gastropods and the entire biota, and the diversification of brachiopods with the Early Devonian global sea-level lowstand, and this may be interpreted as evidence of a certain eustatic control on the marine biodiversity.
\end{abstract}

Key words: bivalves, gastropods, diversity dynamics, origination, extinction, eustatic changes, Silurian, Devonian

\section{Introduction}

The marine biodiversity dynamics has remained on the agenda of international research for decades. The classical works by Sepkoski et al. (1981), Sepkoski (1993), and Benton (1995, 2001) have been followed by Peters \& Foote (2001), Foote (2003, 2006), Bambach (2006), Benton \& Emerson (2007), Alroy et al. (2008), Purdy (2008), Peters \& Heim (2011), and Aberhan \& Kiessling (2012). A possible dependence of the marine biodiversity on eustatic (=global sea-level) changes has also remained a very important subject for debates during the past dec- ades (Newell, 1967; Hallam \& Wignall, 1999; Purdy, 2008; Ruban, 2010a,b; Peters \& Heim, 2011). When some specialists demonstrated that the number of taxa changed in accordance with the fluctuating global sea level (Purdy, 2008; see also the regional study by Sandoval et al., 2001), others emphasised more complex relationships or even their absence (Hallam \& Wignall, 1999; Ruban, 2010b; see also the regional study by McRoberts \& Aberhan, 1997). Moreover, the refinement of the palaeontological material available internationally - from the last compilation of Sepkoski (2002) to the 'PalaeoDB' project (Alroy et al., 2008) - has led 
to changes in the understanding of the eustatic control on marine biodiversity dynamics (Ruban, 2010a).

The above-mentioned debates are highly important now for three additional reasons: (1) the major groups of marine invertebrates tolerated the changing marine environment differently (Ruban, 2007); (2) eustatic controls on biodiversity and influences of the incompleteness of the fossil record are interrelated parameters (Smith \& McGowan, 2011, and references therein); and (3) the nature of the dependence of the marine biodiversity on palaeoenvironmental changes was not permanent (Stanley, 2007). Obviously, none of these reasons implies that the eustatic controls on the marine biodiversity dynamics cannot be established. Thus, it appears to be worthwhile to focus on how the diversity of particular fossil groups might have been controlled by eustatic changes during specific intervals of the geological time. In other words, it remains intriguing whether the eustatic control on the marine biodiversity was so strong that it dominated over the other palaeoenvironmental controls. Solving this task is possible via direct comparisons of global sea-level and biodiversity curves.



Fig. 1. Chronostratigraphy of the analysed interval (after Ogg et al., 2008), correlation of global and regional units (after Menning et al., 2006), and long-term eustatic changes (after Haq \& Schutter, 2008).
The new reconstruction by Haq \& Schutter (2008) depicts the chronology of global sea-level changes through the Palaeozoic. Particularly, it reveals a long-term eustatic cycle that embraces the late Silurian-Middle Devonian time interval (Fig. 1). One can, for instance, hypothesise that the Ludlow-Early Devonian sea-level fall followed by the Middle Devonian sea-level rise could have driven the global diversity dynamics of marine benthic macro-invertebrates directly. The objective of the present contribution is to test this hypothesis for the fossil groups of bivalves and gastropods, which both were rich with respect to the number of genera (Sepkoski, 2002) and which played an important role in the mid-Palaeozoic ecosystems (Forney et al., 1981; Blodgett et al., 1990; Kříž et al., 2003; Jones, 2011; Frýda, 2012). The late Silurian-Middle Devonian interval is chosen for this analysis because it forms part of a more or less symmetric long-term eustatic cycle (Haq \& Schutter, 2008). It also preceded the Late Devonian mass extinctions that stressed the global marine biota so strongly (McGhee, 1996; Hallam \& Wignall, 1997; Racki, 2005) that it masked any 'ordinary' biota/environment relationship.

\section{Materials and methods}

\subsection{Diversity dynamics}

The present contribution is based on two datasets (one on bivalves, and another on gastropods) extracted from the famous palaeontological synthesis by Sepkoski (2002; see also on-line at strata.geology.wisc.edu/jack/start. php). These datasets depict the stratigraphic distribution of genera for the geological time units of the late Silurian-Middle Devonian interval. Undoubtedly, the knowledge of the stratigraphic distribution of both bivalves and gastropods has changed during the past decade (see, e.g., Heildelberger, 2001). Such a kind of incompleteness of data is, however, inevitable, because of common time lag between palaeobiological analyses and the collection of the original data (Ruban, 2012). One possible way to avoid serious errors is to take into account 
the maximum possible uncertainty linked to the incompleteness when the chosen palaeontological data are interpreted (e.g., Ruban, 2011a, 2012).

The documented occurrence of a genus in a given time unit is established as 1.00 , whereas its absence (before origination or after extinction) is established as 0.00 . However, the database by Sepkoski (2002) does not indicate the stratigraphic ranges of several taxa with precision, i.e., the presence/absence of a given taxon is indicated only for a series. In such a case, an equal probability of occurrence of this taxon in each stage of the series is considered (cf. Ruban, 2011a). When it is indicated, for instance, that a specific genus appeared in the Middle Devonian and became extinct in the Frasnian, its presence in the Eifelian and Givetian (these stages constitute the Middle Devonian series) is weighed with the value 0.5 , and its presence in the Frasnian is weighed with the value 1.00. A few taxa with questionable stratigraphic ranges were excluded from the present analysis.

A total of 204 genera of bivalves and 279 genera of gastropods are considered. Three parameters of the taxonomic diversity dynamics of these organisms during the late Silurian-Middle Devonian are analysed. The first parameter is the total generic diversity (TD) dynamics, i.e., changes in the total number of genera. The second and third parameters are changes in the number of originations $(\mathrm{O})$ and extinctions (E). The absence of data on the time intervals earlier and later than that considered always lead to the impossibility to measure the number of originations in the first time unit of the considered interval and the number of extinctions in the last time unit of the considered interval (Ruban \& Van Loon, 2008). To solve this problem, the data on Wenlock and Frasnian bivalves and gastropods from the same source (Sepkoski, 2002) were also involved. The taxonomic diversity dynamics is calculated per epoch for the late Silurian and per age for the Early-Middle Devonian (Fig. 1) because the database of Sepkoski (2002) does not indicate the stratigraphic ranges of Silurian fossils at the level of stages. However, it appears that this difference is an advantage rather than a disadvantage, because the absolute duration of the Silurian epochs is comparable to that of the Early-Middle Devonian ages (Ogg et al., 2008). The probabilistic values employed to deal with imprecise taxa ranges (see above) are considered in the calculation of the TD, $\mathrm{O}$, and E parameters accordingly.

\subsection{Eustatic changes}

The present contribution deals with the long-term eustatic changes, because the duration of the $2^{\text {nd }}$-order and $3^{\text {rd }}$-order cycles is the same or less than that of ages. Indeed, the $2^{\text {nd }}$ - and $3^{\text {rd }}$-order cycles might potentially have affected the biodiversity dynamics, but their influences cannot be recognised in this study, which employs the epoch/age-level resolution of the diversity analysis (see above). The Silurian eustatic reconstructions proposed by Johnson $(2006,2010)$ and reproduced by Ogg et al. (2008) are therefore not considered here. They depict the sea-level cyclicity with a higher resolution than that required for the present study.

The most fresh reconstruction of the mid-Palaeozoic eustatic fluctuations is that of Haq \& Schutter (2008), who updated the earlier version of Haq \& Al-Qahtani (2005). The former depicts both the long- and short-term fluctuations of the global sea level. The long-term eustatic fall started near the end of the Wenlock, accelerated in the late Silurian, and culminated in the early Emsian (Fig. 1). Then, the long-term rise began and peaked in the very beginning of the Frasnian. This global sea-level fall and the subsequent rise lasted for comparable time-spans, and, thus, this eustatic cycle was symmetric.

\subsection{Chronostratigraphical remark}

In his synthesis, Sepkoski (2002) employed the traditional (better to say, regional) stages of the Early Devonian, namely the Gedinne, the Siegen, and the Ems (not to confuse with the standard Emsian stage!). These differ from the global stages adopted by the International 
Commission on Stratigraphy (Ogg et al., 2008). Their correlation established by Menning et al. (2006) is used in order to plot the curves of the global generic diversity dynamics of bivalves and gastropods against the modern chronostratigraphical scale.

\section{Results}

The parameters of the generic diversity of bivalves changed (Fig. 2). It cannot be excluded that the Lau Event (Calner, 2005a,b; Jeppson et al., 2012) was responsible for the registered decline in the total diversity $(\mathrm{TD}=71.5$ in the Ludlow and TD $=54.5$ in the Pridoli) and the relatively high extinction rate $(\mathrm{E}=30$ in the Ludlow) in the late Silurian. A comparison of the bivalve diversity dynamics with the longterm eustatic changes does not reveal any clear coincidence (Fig. 2). However, two interesting features should be noticed: (1) the long-term global eustatic lowstand corresponded to a minor peak in the total diversity and the origination and extinction rates, and (2) the global

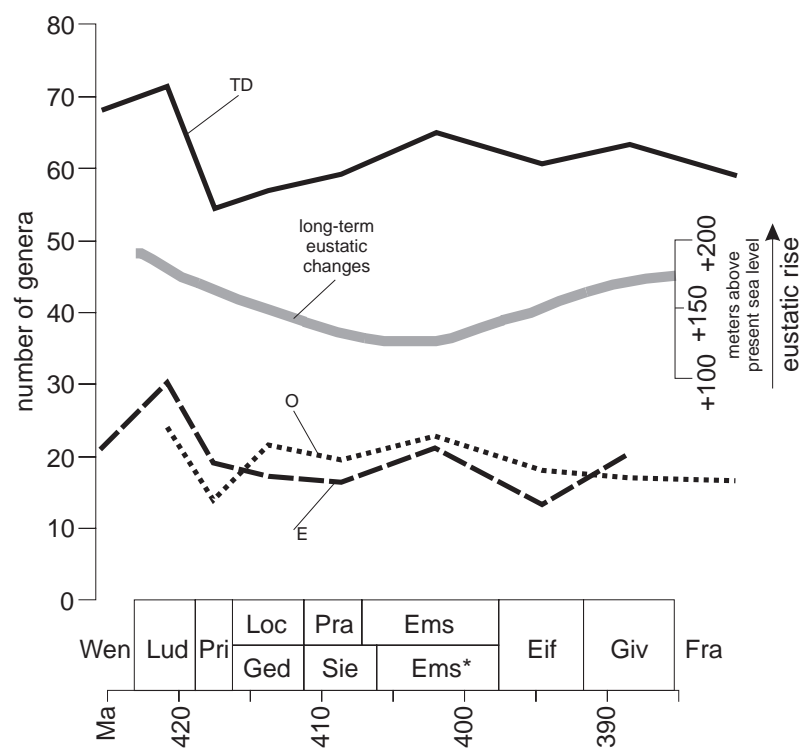

Fig. 2. The late Silurian-Middle Devonian bivalve generic diversity dynamics. Eustatic changes (Haq \& Schutter, 2008) are shown for comparison. The stratigraphic framework follows Figure 1.

Abbreviations of time units: Wen $=$ Wenlock, Lud $=$ Ludlow, Pri $=$ Pridoli, Loc $=$ Lochkovian, Pra $=$ Pragi an, Ems = Emsian, Eif = Eifelian, Giv = Givetian, Fra $=$ Frasnian, $\mathrm{Ged}=$ Gedinne, $\mathrm{Sie}=$ Siegen, $\mathrm{Ems}^{*}=\mathrm{Ems}$ (Koblenz). sea level did not reach its pre-Ludlow height in the Devonian (Haq \& Schutter, 2008); similarly, the Pridoli losses in the total bivalve diversity were not compensated again (at least, this holds clearly for the Lochkovian-Frasnian interval). If these specific features indicate some interdependence between the generic diversity dynamics and the long-term eustatic fluctuations, they provide opposite and, thus, unclear evidence.

The parameters of the generic diversity of gastropods changed significantly through the analysed interval (Fig. 3). The Lau Event (Calner, 2005a,b; Jeppson et al., 2012) might have been responsible for the high rate of extinction in the Ludlow $(\mathrm{E}=40)$ and the decline in the total diversity in the Pridoli (TD $=75$, compared to $\mathrm{TD}=118$ in the Ludlow). The Eifelian crisis (House, 2002) and the Taghanic Event (Walliser, 1996; House, 2002; Baird et al., 2012; Zamb-

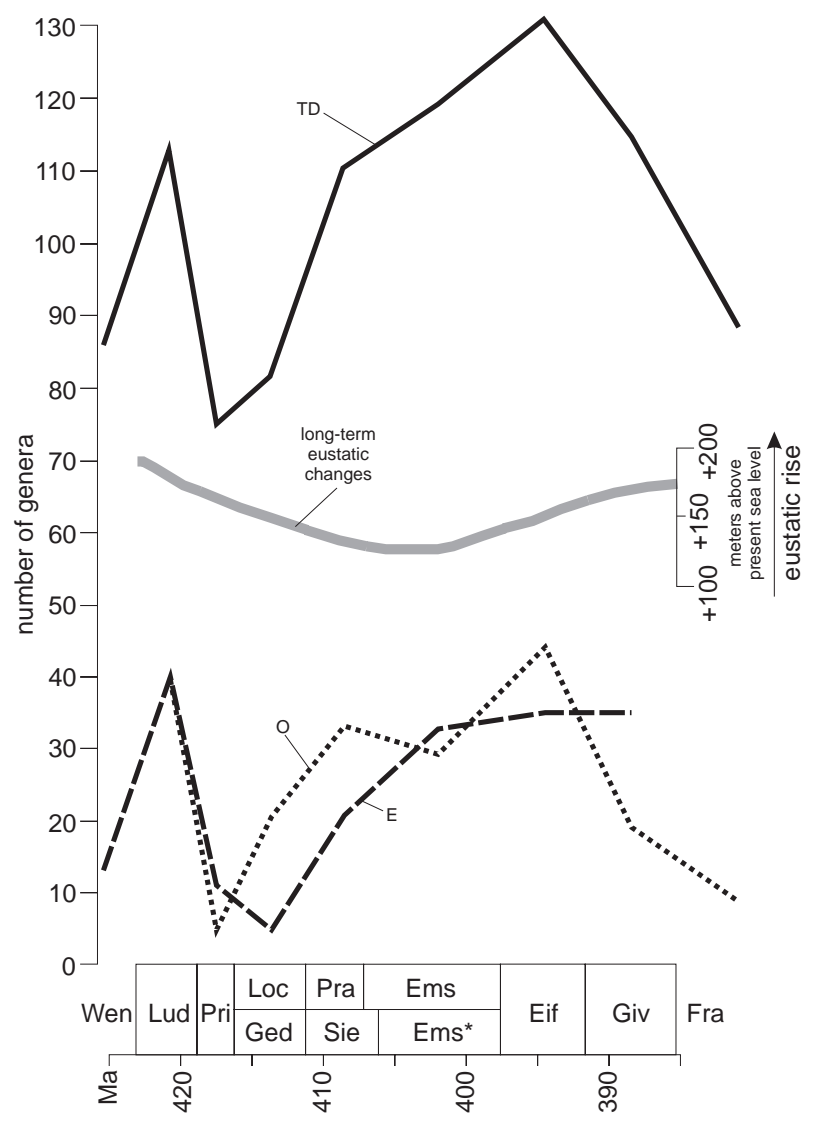

Fig. 3. The late Silurian-Middle Devonian gastropod generic diversity dynamics. Eustatic changes (Haq \& Schutter, 2008) are shown for comparison. The stratigraphic framework follows Figure 1. See Fig. 2 for abbreviations of time units. 
ito et al., 2012) might have been responsible for the strong decline in the total diversity and the origination rate, as well as for the relatively high extinction rates in the Middle Devonian. There was no significant coincidence at all between the gastropod diversity dynamics and the longterm eustatic cycle (Fig. 3). A certain coincidence of the gastropod radiation in the Early Devonian with the global sea-level lowstand is visible, however, which is also documented in the case of bivalves (see Fig. 2 and above).

\section{Discussions and conclusions}

\subsection{General considerations}

As shown by the results presented above, the global generic diversity dynamics of both the bivalves and the gastropods did not coincide with the eustatic cycle during the late Silurian-Middle Devonian. This falsifies the hypothesis formulated in the beginning of the present contribution. Does this imply that the eustatic control on changes in the taxonomic diversity of these important groups of marine benthic macro-invertebrates should be neglected? Such a conclusion requires serious consideration. Global eustatic changes are very complex in their nature. They result from a combination of various mechanisms (tectonic, palaeoclimatic, sedimentary, etc.) operating at both global and regional scales (e.g., Catuneanu, 2006; Veeken, 2006; Moucha et al., 2008; Conrad \& Husson, 2009; Lovell, 2010; Ruban et al., 2012). It cannot be excluded that some large regions with conditions favourable for diversification of marine invertebrates did not undergo submergence despite the global sea-level rise because of large-scale tectonic uplift (e.g., linked to the mechanisms of dynamic topography), and vice versa. For instance, it is well known that the northern margin of Gondwana experienced a regression in spite of the global $2^{\text {nd }}$-order highstand in the Lochkovian, and that the shoreline shifts differed strongly between its various parts (Ruban, 2011b). Moreover, a possible partial control of global sea-level changes on the diversity of bivalves is implied by the two specific features mentioned above.
The late Silurian-Middle Devonian global generic diversity dynamics was, most probably, driven by a series of different extrinsic (i.e., palaeoenvironmental) and intrinsic (i.e., evolutionary) factors such as changes in the temperature of the ancient water masses (Fig. 4). It has been found that the low-latitude sea-surface temperature was relatively high during the late Silurian-earliest Devonian, and that it decreased stepwise during the Early-Middle Devonian (Joachimski et al., 2009). Some cooling also occurred in the Pridoli (Žigaite et al., 2010). These temperature changes coincided with the total diversity dynamics of the gastropods. The number of their genera increased together with the lowering of the sea temperature. In the case of the bivalves, no distinct dependence is found. The above-mentioned biotic crises that occurred in the Ludlow, the Eifelian, and the Givetian (Walliser, 1996; House, 2002; Calner, 2005a,b; Baird et al., 2012; Jeppson et al., 2012; Zambito et al., 2012) are some more examples of the extrinsic control on the diversity changes. This underlines once more that the eustatic control was not more important than the other possible controls on the generic diversity dynamics of the two groups of marine benthic macro-invertebrates under study.

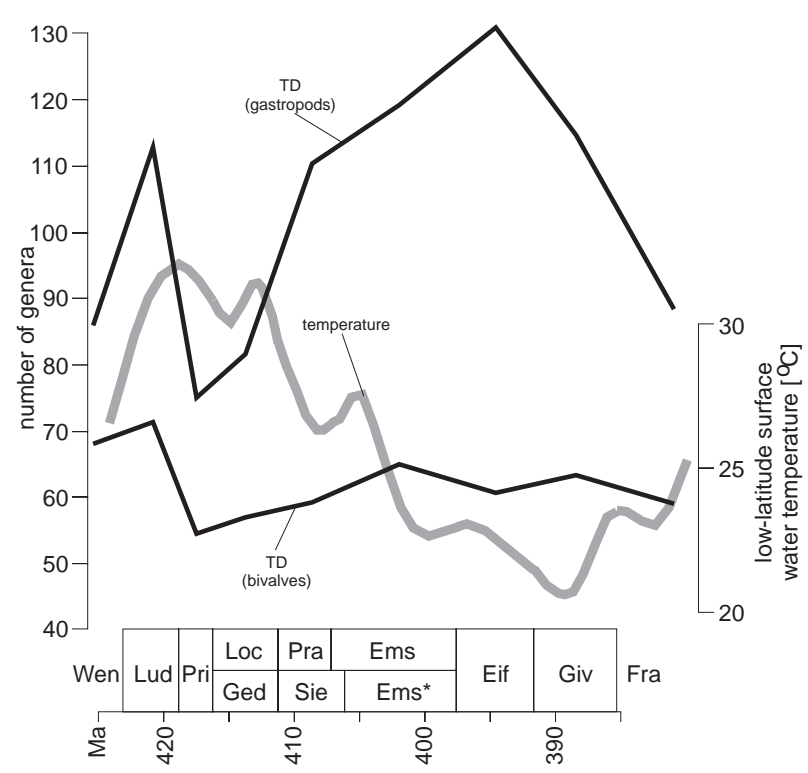

Fig. 4. The late Silurian-Middle Devonian generic diversity dynamics of bivalves and gastropods (this study - see Figs. 2 \& 3) and changes in the low-latitude sea-surface temperature (after Joachimski et al., 2009). 


\subsection{Further comparisons}

It is important to understand whether the absence of evident relationships between the late Silurian-Middle Devonian eustatic changes and the generic diversity dynamics was typical for only bivalves and gastropods or for all marine invertebrates. The available global marine biodiversity curves presented by Purdy et al. (2008) and Alroy et al. (2008), based on the Sepkoski (2002)'s synthesis and the 'PaleoDB' project, respectively, and plotted against the global sea-level curve presented by Haq \& Schutter (2008), provide ambiguous evidence (see Ruban, 2010a). The biodiversity curve of Purdy (2008) indicates some decrease in the number of organisms near the SilurianDevonian transition, but this occurred before the global sea-level reached its peak in the late Early Devonian, as shown by Haq \& Schutter (2008). In contrast, the Alroy et al. (2008) curve demonstrates a reversed coincidence of the eustatic changes and the biodiversity dynamics. The Early Devonian radiation and the following decrease in the number of taxa match the fall, the lowstand, and then the rise of the global sea level that constitute the long-term eustatic cycle (Haq \& Schutter, 2008) discussed above. Anyway, both alternative reconstructions of the marine biodiversity dynamics suggest that the Early Devonian eustatic lowstand coincided with the maximum number of genera, whereas the Middle Devonian eustatic rise coincided with a diminishing number. This feature seems specifically applicable to bivalves.

The present study focuses on two molluskan groups. The relationships between their diversity dynamics and long-term eustatic changes (one might, more appropriately, say: the absence of any evident relationship) should therefore be compared with observations of other groups of marine benthic macro-invertebrates such as brachiopods. The recent increase in knowledge concerning brachiopods enabled Curry \& Brunton (2007) to reconstruct their total generic diversity dynamics with precision. According to these authors, the number of brachiopod genera diminished stepwise during the late Silurian; this was followed by a strong radiation that included the entire Ear- ly Devonian and culminated in the Emsian; then, a gradual, but strong decline took place. Comparing these trends with the long-term eustatic changes reconstructed by Haq \& Schutter (2008), it is evident that the global sea-level lowstand resulted in a higher generic diversity of brachiopods, and that, vice versa, the Middle Devonian eustatic rise coincided with their decline. However, both the total diversity and the global sea level tended to fall during the late Silurian.

Thus, one must deduce that only a partial relationship between these two parameters exists, just like hypothesised for the bivalves (Fig. 2). Based on all this evidence, it is sensible to conclude that - if no strong relationship exists between the fossil diversity dynamics and the long-term eustatic cycle - the Early Devonian lowstand coincided with the maximum number of bivalve genera (Fig. 2), as well as with the start of the gastropod radiation (Fig. 3), the radiation of all marine biota (see above and also Alroy et al., 2008; Purdy, 2008), and the diversification of brachiopods (see above and also Curry \& Brunton, 2007). Such a conclusion is consistent with the recent ideas on global sea-level control on the Early Devonian biotic radiation in the marine realm (Ruban, 2010b). Thus, a eustatic control on the marine biodiversity cannot be totally excluded.

\section{Acknowledgements}

The author gratefully thanks W. Krawczyński (Poland) and another, anonymous, reviewer for constructive suggestions, the editorial team of 'Geologos' for technical support, and also M. Calner (Sweden), C.P. Conrad (U.S.A.), N.M.M. Janssen (The Netherlands), G. Racki (Poland), W. Riegraf (Germany), A.J. van Loon (Poland/Spain/The Netherlands), and other colleagues for generous help with literature.

\section{References}

Aberhan, M. \& Kiessling, W., 2012. Phanerozoic marine biodiversity - a fresh look at data, methods, patterns and processes. [In:] J.A. Talent (Ed.): Earth and life: global biodiversity, extinction intervals and biogeographic perturbations through time. Springer, Dordrecht, 3-22. 
Alroy, J., Aberhan, M., Bottjer, D.J., Foote, M., Fürsich, F.T., Harries, P.J., Hendy, A.J.W., Holland, S.M., Ivany, L.C., Kiessling, W., Kosnik, M.A., Marshall, C.R., McGowan, A.J., Miller, A.I., Olszewski, T.D., Patzkowsky, M.E., Peters, S.E., Viller, L., Wagner, P.J., Bonuso, N., Borkow, P.S., Brenneis, B., Clapham, M.E., Fall, L.M., Ferguson, C.A., Hanson, V.L., Krug, A.Z., Layou, K.M., Leckey, E.H., Nürnberg, S., Powers, C.M., Sessa, J.A., Simpson, C., Tomašových, A. \& Visaggi, C.C., 2008. Phanerozoic trends in the global diversity of marine invertebrates. Science 321, 97-100.

Baird, G.C., Zambito IV, J.J. \& Brett, C.E., 2012. Genesis of unusual lithologies associated with the Late Middle Devonian Taghanic biocrisis in the type Taghanic succession of New York State and Pennsylvania. Palaeogeography, Palaeoclimatology, Palaeoecology 367/368, 121-136.

Bambach, R.K., 2006. Phanerozoic biodiversity and mass extinctions. Annual Review of Earth and Planetary Sciences 34, 127-155.

Benton, M.J., 1995. Diversification and extinction in the history of life. Science 268, 52-58.

Benton, M.J., 2001. Biodiversity on land and in the sea. Geological Journal 36, 211-230.

Benton, M.J. \& Emerson, B.C., 2007. How did life become so diverse? The dynamics of diversification according to the fossil record and molecular phylogenetics. Palaeontology 50, 23-40.

Blodgett, R.B., Rohr, D.M. \& Boucot, A.J., 1990. Early and Middle Devonian gastropod biogeography. [In:] W.S. McKerrow \& C.R. Scotese (Eds): Palaeozoic Palaeogeography and Biogeography. Geological Society Memoir 12, 277-284.

Calner, M., 2005a. Silurian carbonate platforms and extinction events - ecosystem changes exemplified from Gotland, Sweden. Facies 51, 584-591.

Calner, M., 2005b. A Late Silurian extinction event and anachronistic period. Geology 33, 305-308.

Catuneanu, O., 2006. Principles of sequence stratigraphy. Elsevier, Amsterdam, 375 pp.

Conrad, C.P. \& Husson, L., 2009. Influence of dynamic topography on sea level and its rate of change. Lithosphere 1, 110-120.

Curry, G.B. \& Brunton, C.H.C., 2007. Stratigraphic distribution of brachiopods. [In:] P.A. Selden (Ed.): Treatise on invertebrate paleontology 6-H. Brachiopoda. Revised. Geological Society of America, Boulder/University of Kansas, Lawrence, 2901-3081.

Foote, M., 2003. Origination and extinction through the Phanerozoic - a new approach. Journal of Geology 111, 125-148.

Foote, M., 2007. Extinction and quiescence in marine animal genera. Paleobiology 33, 261-272.

Forney, G.G., Boucot, A.J. \& Rohr, D.M., 1981. Silurian and Lower Devonian zoogeography of selected moluscan genera. [In:] J. Gray, A.J. Boucot \& W.B.N. Berry (Eds): Communities of the past. Hutchinson Ross, Stroudsberg, 119-164.

Frýda, J., 2012. Phylogeny of Palaeozoic gastropods Inferred from their ontogeny. [In:] J.A. Talent (Ed.): Earth and life - global biodiversity, extinction intervals and biogeographic perturbations through time. Springer, Dordrecht, 395-435.

Hallam, A. \& Wignall, P.B., 1997. Mass extinctions and their aftermath. Oxford University Press, Oxford, 320 pp.

Hallam, A. \& Wignall, P.B., 1999. Mass extinctions and sea-level changes. Earth-Science Reviews 48, 217-250.

Haq, B.U. \& Al-Qahtani, A.M., 2005. Phanerozoic cycles of sea-level change on the Arabian Platform. GeoArabia 10, 127-160.

Haq, B.U. \& Schutter, S.R., 2008. A chronology of Paleozoic sea-level changes. Science 322, 64-68.

Heildelberger, D., 2001. Mitteldevonische (Givetische) Gastropoden (Mollusca) aus der Lahnmuld (südliches Rheinisches Schiefergebirge). Geologische $A b$ handlungen Hessen 106, 291 pp.

House, M.R., 2002. Strength, timing, setting and cause of mid-Palaeozoic extinctions. Palaeogeography, Palaeoclimatology, Palaeoecology 181, 5-25.

Jeppson, L., Talent, J.A., Mawson, R., Andrew, A., Corradini, C., Simpson, A.J., Wigforss-Lange, J. \& Schönlaub, H.P., 2012. Late Ludfordian correlations and the Lau Event. [In:] J.A. Talent (Ed.): Earth and life - global biodiversity, xxtinction intervals and biogeographic perturbations through time. Springer, Dordrecht, 653-675.

Joachimski, M.M., Breisig, S., Buggisch, W., Talent, J.A., Mawson, R., Gereke, M., Morow, J.R., Day, J. \& Weddige, K., 2009. Devonian climate and reef evolution: Insights from oxygen isotopes in apatite. Earth and Planetary Science Letters 284, 599-609.

Johnson, M.E., 2006. Relationship of Silurian sea-level fluctuations to oceanic episodes and events. GFF 128, 115-121.

Johnson, M.E., 2010. Tracking Silurian eustasy: alignment of empirical evidence or pursuit of deductive reasoning? Palaeogeography, Palaeoclimatology, Palaeoecology 296, 276-284.

Jones, R.W., 2011. Applications of palaeontology - techniques and case studies. Cambridge University Press, Cambridge, $406 \mathrm{pp}$.

Křriž, J., Degardin, J.M., Ferretti, A., Hansch, W., Gutiérrez Marco, J.C., Paris, F., Piçarra-D-Almeida, J.M., Robardet, M., Schönlaub, H.P. \& Serpagli, E., 2003. Silurian stratigraphy and paleogeography of Gondwanan and Perunican Europe. [In:] E. Landing \& M.E. Johnson (Eds): Silurian lands and seas - paleogeography outside of Laurentia. New York State Museum Bulletin 493, 105-178.

Lovell, B., 2010. A pulse in the planet: regional control of high-frequency changes in relative sea level by mantle convection. Journal of the Geological Society, London 167, 637-648.

McGhee, G.R., 1996. The Late Devonian mass extinction - the Frasnian-Famennian crisis. Columbia University Press, New York, 303 pp.

McRoberts, C.A. \& Aberhan, M., 1997. Marine diversity and sea-level changes: numerical tests for association using Early Jurassic bivalves. International Journal of Earth Sciences 86, 160-167.

Menning, M., Alekseev, A.S., Chuvashov, B.I., Davydov, V.I., Devuyst, F.-X., Forke, H.C., Grunt, T.A., Hance, L., Heckel, P.H., Izokh, N.G., Jin, Y.-G., Jones, P.J., Kot- 
lyar, G.V., Kozur, H.W., Nemyrovska, T.I., Schneider, J.W., Wang, X.-D., Weddige, K., Weyer, D. \& Work, D.M., 2006. Global time scale and regional stratigraphic reference scales of central and West Europe, East Europe, Tethys, South China, and North America as used in the Devonian-Carboniferous-Permian Correlation Chart 2003 (DCP 2003). Palaeogeography, Palaeoclimatology, Palaeoecology 240, 318-372.

Moucha, R., Forte, A.M., Mitrovica, J.X., Rowley, D.B., Quere, S., Simons, N.A. \& Grand, S.P., 2008. Dynamic topography and long-term sea-level variations: there is no such thing as a stable continental platform. Earth and Planetary Science Letters 271, 101-108.

Newell, N.D., 1967. Revolutions in the history of life. Geological Society of America Special Paper 89, 63-91.

Ogg, J.G., Ogg, G. \& Gradstein, F.M., 2008. The concise geologic time scale. Cambridge University Press, Cambridge, 177 pp.

Peters, S.E. \& Foote, M., 2001. Biodiversity in the Phanerozoic: a reinterpretation. Paleobiology 27, 583-601.

Peters, S.E. \& Heim, N.A., 2011. Stratigraphic distribution of marine fossils in North America. Geology 39, 259-262.

Purdy, E.G., 2008. Comparison of taxonomic diversity, strontium isotope and sea-level patterns. International Journal of Earth Sciences 97, 651-664.

Racki, G., 2005. Towards understanding Late Devonian global events: few answers, many questions. [In:] D.J. Over, J.R. Morrow \& P.B. Wignall (Eds): Understanding Late Devonian and Permian-Triassic biotic and climatic events - towards an integrated approach. Elsevier, Amsterdam, 5-36.

Ruban, D.A., 2007. Jurassic transgressions and regressions in the Caucasus (northern Neotethys Ocean) and their influences on the marine biodiversity. Palaeogeography, Palaeoclimatology, Palaeoecology 251, 422-436.

Ruban, D.A., 2010a. Do new reconstructions clarify the relationships between the Phanerozoic diversity dynamics of marine invertebrates and long-term eustatic trends? Annales de Paléontologie 96, 51-59.

Ruban, D.A., 2010b. Palaeoenvironmental setting (glaciations, sea level, and plate tectonics) of Palaeozoic major radiations in the marine realm. Annales de Paléontologie 96, 143-158.

Ruban, D.A., 2011a. Do outdated palaeontological data produce just a noise? An assessment of the Middle Devonian-Mississippian biodiversity dynamics in central Asia on the basis of Soviet-time compilations. Geologos 17, 29-47.

Ruban, D.A., 2011b. Lochkovian (earliest Devonian) transgressions and regressions along the "Tethyan" margin of Gondwana: a review of lithostratigraphical data. Gondwana Research 20, 739-744.

Ruban, D.A., 2012. Reply to "Comment: Taxonomic diversity structure of Silurian crinoids: Stability versus dynamism" by S.K. Donovan. Annales de Paléontologie 98, 317-320.

Ruban, D.A. \& van Loon, A.J., 2008. Possible pitfalls in the procedure for paleobiodiversity-dynamics analysis. Geologos 14, 37-50.

Ruban, D.A., Zorina, S.O., Conrad, C. P. \& Afanasieva, N.I., 2012. In quest of Paleocene global-scale transgressions and regressions: constraints from a synthesis of regional trends. Proceedings of the Geologists' Associations 123, 7-18.

Sandoval, J., O'Dogherty, L. \& Guex, J., 2001a. Evolutionary rates of Jurassic ammonites in relation to sea-level fluctuations. Palaios 16, 311-335.

Sepkoski, J.J., 1993. Ten years in the library: New data confirm paleontological patterns. Paleobiology 19, 43-51.

Sepkoski, J.J., Jr., 2002. A compendium of fossil marine animal genera. Bulletins of American Paleontology 363, 560 pp.

Sepkoski, J.J., Bambach, R.K., Raup, D.M. \& Valentine, J.W., 1981. Phanerozoic marine diversity and fossil record. Nature 293, 435-437.

Smith, A.B. \& McGowan, A.J., 2011. The ties linking rock and fossil records and why they are important for palaeobiodiversity studies. [In:] A.J. McGowan \& A.B. Smith (Eds): Comparing the geological and fossil records - implications for biodiversity studies. Geological Society, London, Special Publications 358, 1-7.

Stanley, S.M., 2007. An analysis of the history of marine animal diversity. Paleobiology 33 (sp6), 1-55.

Veeken, P.C.H., 2006. Seismic stratigraphy, basin analysis and reservoir characterisation. Elsevier, Amsterdam, 509 pp.

Walliser, O.H., 1996. Global events in the Devonian and Carboniferous. [In:] O.H. Walliser (Ed.): Global events and event stratigraphy in the Phanerozoic. Springer, Berlin, 225-250.

Zambito, J.J., IV, Brett, C.E. \& Baird, G.C., 2012. The Late Middle Devonian (Givetian) global Taghanic biocrisis in its type area (Northern Appalachian Basin): geologically rapid faunal transitions driven by global and local environmental changes. [In:] J.A.S. Talent (Ed.): Earth and life - global biodiversity, extinction intervals and biogeographic perturbations through time. Springer, Dordrecht, 677-703.

Žigaitė, Z., Joachimski, M., Lehnert, O. \& Brazauskas, A., 2010. $\delta^{18} \mathrm{O}$ composition from conodont apatite indicates climate cooling during the Middle Pridoli. Palaeogeography, Palaeoclimatology, Palaeoecology 294, 242-247.

Manuscript received: 2 June 2012 Revision accepted: 22 December 2012 